УДК 128

DOI: 10.18101/1994-0866-2020-2-21-27

\title{
ПОЛЕМИКА ОТЦОВ ХРИСТИАНСКОЙ ЦЕРКВИ О СВОБОДЕ ВОЛИ И СУЩЕСТВОВАНИИ ЧЕЛОВЕКА
}

\begin{abstract}
(c) Рукин Александр Валентинович
кандидат философских наук, доцент кафедры гуманитарных

и социально-экономических дисциплин,

Военная академия воздушно-космической обороны имени Маршала Г. К. Жукова

Россия, 170100, г. Тверь, ул. Жигарева, 50

E-mail: rukin.tver@yandex.ru

В современной науке не выработана единая и непротиворечивая теория, раскрывающая сущность человека. Актуальность исследований человека определяется традиционным научным интересом к объяснению природы человека и смысла его существования. Статья продолжает цикл авторских работ, посвященных изучению сущности и существования человека. Необходимость проведенного в статье анализа определяется тем, что герменевтическая интерпретация философских текстов в новых исторических условиях позволяет формировать целевые установки в решении проблемы человека. Цель статьи - проанализировать эволюцию философских представлений о сущности и существовании человека в мировоззрении отцов христианской церкви, которое наиболее ярко проявилось в творчестве Августина, Фомы Аквинского, Пелагия, Мартина Лютера, Эразма Роттердамского, полемизирующих о свободе воли человека и ответственности человека за свой индивидуальный способ существования. В исследовании используется герменевтический анализ текста. Анализ полемики христианских мыслителей позволяет углубить понимание человека и его индивидуальной жизни. Ключевые слова: Бог; человек; свобода; сущность и существование человека; ответственность; Августин; Фома Аквинский; Пелагий; Мартин Лютер; Эразм Ротердамский.
\end{abstract}

\section{Для цитирования}

Рукин A. B. Полемика отцов христианской церкви о свободе воли и существовании человека // Вестник Бурятского государственного университета. Философия. 2020. Вып. 2. С. 27-27.

В современной науке усиливается тенденция, нацеленная на изучение природы человека. Прежде всего в объяснении природы человека нуждаются разработчики искусственного интеллекта и роботизированной техники.

Раскрыть природу человека может лишь философия, в силу своего эвристического потенциала. Вместе с тем в современной философской мысли существует множество противоречивых концепций и подходов к толкованию человеческой природы. Специфика философского знания в том, что мыслители прошлого в личностном рефлексивном опыте осмысления природы человека смогли объяснить отдельные стороны человеческой сущности, которые подтверждаются данными современной науки. Обращение к философскому наследию помогает современному исследователю определить перспективное направление в изучении сущностных характеристик человека. 
A. B. Рукин. Полемика отцов христианской церкви о свободе воли и существовании человека

Данная статья продолжает цикл авторских работ, посвященных изучению природы человека и его жизненного пути в интересах разработки информационного подхода. Значительную сложность представляет объяснение механизма перехода от сущности человека к его поступкам, т. е. переход от сущности к явлению. Полемика отцов христианской церкви о свободе воли человека позволяет раскрыть варианты решения вопроса о механизме перехода от сущности человека к его поступкам.

В европейской философской традиции наиболее значимый вклад в рассмотрение проблемы свободы воли внесли отцы христианской церкви: Августин, Фома Аквинский, Пелагий, Мартин Лютер, Эразм Ротердамский. Они в мировоззренческих столкновениях по решению фундаментального вопроса веры о взаимоотношении Бога и человека заострили проблему свободной воли человека, прежде всего, показав, что свобода субъекта определяет его ответственность. Тем самым христианские мыслители углубили понимание индивидуальной жизни человека.

Фундаментальность вопроса свободной воли человека проявляется в пелагианском споре. Августин ожесточенно полемизировал с Пелагием по проблеме понимания свободной воли и ее роли в спасении человека, закончившейся осуждением Церковью пелагианства как ереси.

Аврелий Августин (лат. Aurelius Augustinus Hipponensis) или Агустин Блаженный (354-430г.) — христианский богослов и философ, епископ Гиппонский (Гиппон, близ Карфагена, Северная Африка), родился в африканской провинции, городе Тагаст.

Пелагий (360-410 г.) предположительно родился в Бретани (регион на северо-западе современной Франции), известный ересиар - представитель еретического учения о первородном грехе и человеческой силе, противостояния первородному греху.

Пелагий, не отрицавший помощи Бога в спасении человека, считал, что первородный грех - это личный грех Адама, он не распространяется на потомков. В силу этого каждый рождающийся человек рождается таким, каким был сотворен первый человек. Каждый потомок обладает свободой воли избрать путь греха или путь самовозвышения до этического совершенства Христа. Человек посредством свершения благих поступков может заслужить спасение.

Таким образом, в пелагианской модели человек обладает свободой воли и свободен в выборе своего жизненного пути, однако свои поступки человек выбирает ради получения награды, даруемой Богом за праведные дела, а это уже не свободный выбор, это выбор способа существования и конкретных поступков, обусловленный волей дарующего награду.

Августин утверждает свободную волю человека как благодать, даруемую Богом. Для Августина все блага происходят от Бога, и свободная воля даруется человеку Богом, ибо без свободной воли никто не может жить праведно. Однако от решения самого человека зависит использование свободной воли, поэтому следует обвинять тех людей, кто использует данную свыше свободную волю для свершения постыдных поступков [3].

По Августину, свободная воля есть божественный дар. Изначально данная свободная воля могла не грешить, но могла и грешить. Ошибка человека, а именно 
первородный грех, отдалила его от истинного Бога. Будущая свобода, даруемая Богом, - это свобода, при которой человек будет поставлен в состояние невозможности грешить, ибо он не захочет грешить потому, что грех не будет доставлять ему удовольствие. Человек перестанет завидовать другому, имеющему большее благо, и желать себе большего блага, чем имеет. Эта более могущественная свобода, наполненная добром, характеризующая причастие человека к Богу, даруется через очищение первой свободы от зла и своей вины при посредстве благодати [2].

Таким образом, в модели Августина человек рождается с греховной природой, с которой свободная воля человека не имеет сил бороться и поэтому человек склонен выбирать грех. Спасти человека может только благодать Бога, даруемая человеку независимо от его заслуг в свершении благих дел. Благодать изменяет человека, он получает высшую свободу и освобождается от своей греховной природы и тяги к греху. Августин считает, что Бог - источник подлинной свободы воли человека. Надежда и ожидание благодати - такова судьба августиновского человека.

Фома Аквинский развивает христианскую модель свободной воли, гармонизируя взаимодействие интеллекта и воли человека. Фома Аквинский (лат. Thomas Aquinas, ок. 1225-1274) - философ и теолог, канонизирован католической церковью как учитель Церкви, родился близ Аквино (нынешняя Италия). Один из наиболее влиятельных философов средневековой эпохи, сформулировал пять доказательств бытия Бога. Воля человека рассматривается Аквинским как разумная целеустремленность на желаемое благо. Свобода действия присуща воле в любом естественном состоянии и относительно любого объекта. Интеллект определяет цели действия и направляет волю, воля, в свою очередь, побуждает к действию, в том числе и сам интеллект. Достижение желаемого блага реализует свободу человека, достигающего состояние блаженства. Само стремление к блаженству является необходимостью по отношению к воле, которая не может не иметь стремления к блаженству. Однако из показанных разумом совокупности благ воля свободна в выборе конкретного блага как цели своего стремления, иначе человек был бы освобожден от ответственности за свою деятельность.

Аквинский выделяет частные блага, которые не связаны с Богом, и Высшее благо, которое есть Бог. Изначальной целеустремленностью к Богу обладают лишь праведники, их стремление к Высшему благу обусловлено естественной необходимостью, ибо это стремление и есть проявление их свободной воли, которая не желает другого блага. Люди, не имеющие естественного стремления к Высшему благу, ориентированы на частное благо. Несовершенство разума, ограниченность знаний человека порождают ошибки в выборе и действиях. Заблуждение порождается разумом, который может направлять волю на стремление к малозначимому частному благу. В этом единстве поиска заблуждающегося разума и направляемого им стремления воли достигнуть ошибочную цель и опять вернуться к поиску новой цели и проявляется свобода воли человека как свобода разумного стремления.

Таким образом, Аквинский считает, что человек имеет свободу воли как свободу разумного стремления, которое позволяет через собственное интеллектуально-волевое развитие достичь блаженства, посредством свободного 
A. B. Рукин. Полемика отцов христианской церкви о свободе воли и существовании человека

выбора своего стремления к Высшему благу. Разум предлагает лишь набор альтернатив, выбор обусловливается волей, в которой проявляется желание и стремление человека. Поэтому выбор зла и отказ от добра есть выбор самого человека, ибо его воля свободна, и он должен нести ответственность за свой выбор. Аквинский, освобождая волю человека, освобождает Бога от ответственности за устремления свободной воли человека, т. е. распределение свобод, распределяет ответственность.

Проблема свободной воли человека оказалась в фокусе ожесточенной полемики, в которой ощущается могучее движение и столкновение церковных и политических сил возрожденческой эпохи, гуманиста эпохи Возрождения Эразма Роттердамского, выступившего с диатрибой «О свободной воле», и христианского богослова, инициатора Реформации Мартина Лютера, ответившего работой «О рабстве воли».

Эразм Роттердамский лат. Erasmus Roterodamus, настоящее имя Герхард Герхардс (около 1469-1536 г.), родился близ Роттердама (Нидерланды). Эразм Роттердамский один из наиболее известных гуманистов, священник августинского монастыря, в течение нескольких лет преподавал греческий язык и богословие в Кембридже, советник короля Испании Карла I. Эразм не принял Реформацию и в конце жизни остро полемизировал с Лютером по поводу доктрины свободы воли.

Мартин Лютер нем. Martin Luther (1483-1546) родился в Айслебене, Саксония (в современной Германии Лютерштадт Айслебен - назван в честь Мартина Лютера), христианский богослов, инициатор Реформации и возникновения протестантизма - лютеранства, переводчик Библии на немецкий язык, монах в монастыре августинцев, преподаватель в Виттенбергском университете. После поездки в Рим в 95 тезисах резко обличает пороки Католической церкви, отрицает непогрешимость Папы Римского, открыто осуждает торговлю индульгенциями.

Эразм Роттердамский в полемике с Лютером обосновывает наличие свободной воли человека через противопоставление тезиса и антитезиса. Если человек действует по абсолютной необходимости, т. е. добрые и злые дела свершаются человеком не по своей воле, а по воле Бога, тогда, с одной стороны, нет заслуги самого человека в добрых деяниях, с другой — человек не должен нести ответственность за свершение зла. Но приписывание существования зла свободной воле Бога противоречит священному писанию, логике суждений и социальной реальности.

Поступки человека, по Эразму, обусловливаются действием двух причин Божьей благодатью и человеческой волей. В действиях человека выделяется начало, продвижение и завершение. Побудительное начало и результат человеческой активности определяются благодатью как главной причиной человеческой активности, а в продвижении, т. е. непосредственном действии, проявляется свобода человеческой воли как вторичной по отношению к главной причине - Богу.

Таким образом, Эразм считает, что свободная воля человека ничего не может, если ей не поможет благодать. Однако человек по своей воле может принять помощь или отказаться от нее, либо по своей воле совершать нечто противоречащее 
смыслу оказываемой помощи. В таком случае ответственность за жестокость и несправедливость ложится на того, кто совершает зло, отказавшись от благодати Бога [11]. Иными словами, человек, совершающий зло и насилие, ответственен за свой способ существования, ибо сам выбрал свою жизнь.

Для Лютера, апеллировавшего к Августину, в вопросах веры проблема свободной воли является фундаментальной, ибо существование благодати не терпит рядом с собой существования хоть какой-нибудь частицы или силы свободной воли $[5 ; 6]$.

Свободная воля, по Лютеру, неизбежно порождает господство субъекта свободной воли, который стремится в своих действиях реализовать стремления своей свободной воли, а это и есть проявление господства над объектом стремления свободной воли. В лютеровской иерархии отношений «Бог - человек - природа» человек поставлен господином над теми, кто ниже его, и над ними имеет он право и свободную волю, чтобы они повиновались ему и делали то, что он хочет и о чем помышляет. В отношении же к Богу у человека нет свободной воли, ибо человек ничего не может принять, если не будет это дано ему с неба. Бог имеет по отношению к человеку свободную волю, дабы человек хотел и делал то, что хочет Бог, и не мог ничего, если Бог не захочет и не сделает [6].

Основным пафосом мировоззрения Лютера является убеждение, что проявления свободной воли и благие поступки ничего не значат, если внутри человека нет веры в Христа, то есть стремления свободной воли на преодоление своей природной греховности ничего не значат, ибо грех не в теле, а в том, что не веруют в Христа, грех в самом разуме и волении. Лютер утверждает христианскую свободу исповеди и покаяния [5].

В рабство воля человека попадает, когда он провозглашает, что в отношении к Богу имеет свободную волю. Человек свободной воли стремится заслужить спасение посредством свершения благих поступков и, прежде всего, с выбора самой веры в Христа. Свободная воля превращает Христа в неумолимого судью, оценивающего свершенные человеком поступки, а это и есть неверие в Христа. Вера в Христа показывает, что Он ходатайствует за человека перед Богом и своей кровью обрел для него благодать, поэтому оправдание получит человек благодаря своей вере в Христа как посредника и милостивейшего Спасителя.

Лютер, прежде всего, осуждает проявление свободной воли человека в отношении к Богу, лютеровское «рабство воли» предполагает относительность воли человека в отношении к абсолютной свободной воле Бога. Лютер стремится показать, что обладание человеком свободой воли в отношении к Богу таит в себе угрозу ее абсолютизации, что неизбежно приведет к ее вырождению в произвол. Человек наделен свободой воли лишь к тому, что ниже его в лютеровской иерархии, ибо свобода воли рождает господство.

Таким образом, в отличие от Лютера, Эрразм показывает, что человек обладает свободой воли и в отношении к Богу. Человек свободен в выборе решения отказаться или принять помощь Бога, направляющего человека к божественной благодати, при этом ответственность за выбор конкретного поступка и индивидуального способа существования ложится на самого человека.

Итак, проведенный анализ позволяет сформулировать вывод о том, что полемика христианских мыслителей о свободе воли и существовании человека 
A. B. Рукин. Полемика отцов христианской церкви о свободе воли и существовании человека

развивает философские представления о природе человека и его индивидуальной жизни. Так Пелагий считает, что Бог дарует человеку благодать за праведные дела. Пелагий, несмотря на утверждение о свободной воле человека, позволяющей выбирать свой способ существования, закрепощает ее стремлением к награде за праведные дела.

Августин отвергает свободную волю человека, подчиняющего свое существование непреодолимой греховности. Иными словами, по Августину, греховная сущность человека определяет его греховный способ существования. Спасти может только Бог, дарующий человеку полную свободу от греха, которую невозможно купить или заработать. Существование человека характеризуется надеждой и ожиданием благодати.

Аквинский считает, что человек свободен в выборе своих поступков и личного способа существования. Свободная воля человека определяет ответственность самого человека за выбор своей жизни, посвященной утверждению добра или зла.

Эразм подчеркивает зависимость свободы воли человека от помощи благодати. Человек ограничен в свободе своей воли, он может выбрать помощь благодати или отказаться от нее, совершая противоречащие благодати поступки. Человек, совершая зло в своей жизни, выбирает и свою собственную сущность, за которую должен отвечать только сам человек.

Полемизируя с Эразмом, Лютер считает, что признание свободы воли человека может привести к ее вырождению в произвол. Произвол как проявление абсолютной свободы порождает насилие и зло. Для Лютера греховность существования человека определяется не греховностью его тела, а греховностью его духа, его неверием в Христа. Иными словами, греховная сущность человека не может быть оправдана его благими поступками и добропорядочным существованием.

\section{Литература}

1. Аврелий Августин. Исповедь. М.: Республика, 1992. 332 с.

2. Августин Блаженный. О Граде Божием. Минск: Харвест; М.: АСТ, 2000. 662 с.

3. Августин Блаженный. О свободе воли // Антология средневековой мысли: в 2 т. СПб.: Изд-во РХГИ, 2001. Т. 1. С. 19-112.

4. Бирюков Д. С. Ересь и еретики. СПб.: Амфора: Русская Христианская гуманитарная академия, 2011. 474 с.

5. Лютер М. О свободе христианина // 95 тезисов / сост., вступ. ст., примеч. и коммент. И. Фокина. СПб.: Роза мира, 2002. 720 с.

6. Лютер М. О рабстве воли // Эразм Роттердамский. Философские произведения. М.: Наука, 1987. С. 290-545.

7. Лютер М. Избранные произведения. СПб., 1997. 340 с.

8. Перевезенцев С. В. Антология философии средних веков и эпохи Возрождения. М.: ОЛМА-ПРЕСС, 2001. 448 с.

9. Свежавски С. Фома Аквинский. М.: МЦИФИ, 2000. 212 с.

10. Соколов В. В. Средневековая философия. СПб.: ЛКИ, 2010. 352 с.

11. Эразм Роттердамский. Диатриба, или рассуждение о свободе. Философские произведения. М.: Наука, 1987. 762 с.

12. Фома Аквинский. Сочинения. Челябинск: Билингва, 2010. Вып. 2. 570 с. 


\title{
DISCUSSION OF THE CHURCH FATHERS
}

ON THE FREE WILL AND EXISTENCE OF A HUMAN

\author{
Aleksandr V. Rukin \\ Cand. Sci. (Philos.), A/Prof. of Humanities \\ and Socio-Economic Disciplines Department, \\ Zhukov Air and Space Defence Academy \\ 50 Zhigareva St., Tver 170100, Russia \\ E-mail: rukin.tver@yandex.ru
}

Up to the present in modern science there is no a unified and consistent theory revealing the human's nature. The relevance of human subject research is determined by traditional scientific interest in explaining the human's nature and the reason for his existence. The article continues the series of own works devoted to the study of the human's nature and existence. The need for the analysis carried out in the article is determined by the fact that the hermeneutical interpretation of philosophical texts in the new historical environment allows us to formulate goals in solving the human problem. The article analyzes the evolution of philosophical ideas about the human's nature and existence in the worldview of the Church Fathers, which manifested itself in the works of Augustine, Thomas Aquinas, Pelagius, Martin Luther, Erasmus of Rotterdam, who polemized about human free will and human responsibility for his individual way of existence. The study uses hermeneutic text analysis. The analysis of Christian thinkers' polemic allows us to deepen our understanding of the human and his individual life.

Keywords: God; human; freedom; human's nature and existence; responsibility; Augustine; Thomas Aquinas; Pelagius; Martin Luther; Erasmus of Rotherdam. 